\title{
Law as an argumentative practice: On the pitfalls of confirmatory research, false necessities, and (Kantian) stupidity - Comments on Knut Traisbach
}

\author{
F R I E D R I C H K R A T O C H W I L \\ European University Institute (Emeritus), Via dei Roccettini 9, 50014 San Domenico di Fiesole (FI), \\ Italy
}

Email: Friedrich.Kratochwil@eui.eu

\begin{abstract}
The comment expands the logic of the critique of the 'judicialisation' in the global era and suggests that arguments in support of this development often engage in confirmatory research which weighs the 'evidence' in light of our wishes and political projects. The talk about 'learning' and 'dialogue' cannot sustain this form of judicial paternalism (at best) as an instantiation of emancipation or celebrate it as a victory for law by dispensing with politics. It is just a politics by other means. But in this politics some traditional remedies for insuring the accountability of the 'rulers' (or rule-handlers) have been weakened. The comment adds several critical observations about the practices of discourse, law, politics and judging which cannot camouflage the problem of power and its legitimisation. Thus we had better consider also a political alternative which relies on a variety of different institutional solutions where courts have to compete with other institutions without fixed hierarchies and where different sources of legitimacy stand in tension with each other.
\end{abstract}

Keywords: confirmatory research; functional legitimisation; ideal speech situations; praxis of judging

Knut Traisbach provides us with a critical overview of the dominant discourse on 'judicialisation' in the global era and of the various arguments that purport to show that all is for the good. Not only will the fragmentation of the international legal order be overcome, the community of courts will also compensate for the disaggregation of the state, and a new discursive space - insulated from politics - will emerge so that judges, committed to the same values, can devote themselves to the identification and solution of common problems. They can legitimately do this by virtue of their emerging judicial authority that can substitute for the weakened capacity of the domestic political orders. 
Of course, some evidence can be proffered for any of those propositions: judges of high courts do defer at times to those of other jurisdictions, ${ }^{1}$ and new sources of legitimacy have arisen which have altered the old notion of territorial sovereignty which formerly could - if at all - only be limited by acts of self-limitation. Here both the notion of judicial review domestically and the resonance of human rights internationally provide the examples. But whether the evidence can also carry the weight of the entire argument is, of course, another matter. Thus even if the 'juristocrats' of today are increasingly in dialogue with each other across countries, jurisdiction or fields - be they judges, administrative officials in national and international public or private institutions or even legal theorists concerned with the future of the global order - the second part of the above claim concerning their 'authority' to seize the power from traditional institutions is a rather tall order to fill. This is the case especially now as we observe the apparently rapid growth of 'populism' in Europe and elsewhere. While the latter phenomenon does, of course, not simply show that traditional structures are regaining the upper hand, as some realists of yore might argue, it does thereby prove that we are probably not on the presumably well-charted and familiar road to a full-fledged cosmopolitan order.

Here, Traisbach's criticisms are well taken and they singly and in conjunction remind us that when we evaluate evidence we have to do so not only by confronting it with counter-evidence and by assessing the probative value of one proposition with that of other appraisals, we also must not submit to the fallacy of composition since even if every proposition singly is true, the 'whole' might not be. All of that should make us rather cautious, notwithstanding the traditional (mis-)use of the logical principle of the excluded middle (tertium non datur).

I.

One could now object that this principle of logic might be applicable only to 'true' propositions anyway and thus perhaps not to assessments, or appraisals, which are common in law and the realm of praxis. ${ }^{2}$ While there might be something to this, to be sure we would have again to provide

1 Although such a deference is conceptually ambiguous since it is certainly not a deference to foreign judicial decisions that are treated like a 'precedent'. Rather foreign decisions are cited only in support of the court's own claim that its construction of the law is in accordance with certain trends in, e.g., articulating new (customary) rules or in interpreting existing ones whose meaning is not plain due to the inevitable semantic openness of our concepts.

2 Assessments (or appraisals) have a necessary evaluative dimension which exceeds that of an assertion; see also F Kratochwil, Praxis: On Acting and Knowing (Cambridge University Press, Cambridge, 2018). 
some support for that hunch and then the question would arise why logic should not be applicable across the board or why a different logic has to prevail, as Kant pointed out, for example, in regard to aesthetic judgments in his Third Critique.

Without wanting to get into this controversy, I will try to get at it only obliquely by focusing mainly on the first step for which Traisbach has provided us with much food for thought: the 'weighing' of the evidence. In this sense, I want to push the 'logic' of his argument a bit further, without attributing those arguments to Traisbach himself. I want to do so not because such a strategy allows me to avoid a direct engagement with what an author said, but on the contrary to probe the implications of what he meant and on which he did or could not elaborate given the limitations of the presentational format. This seems to be a much more proper engagement than just listing the surface agreements or disagreements. To that extent I shall use Weber's 'ideal type' as a heuristic device whose power does not lie in accurate representation of what is observed but in 'overdrawing' some characteristic so that we can figure out why those assessments mentioned above seem to many so persuasive. I shall therefore focus on two interconnected points.

One is the realisation that most of the arguments made in those contexts engage in wildly 'confirmatory' research, which violates the standards of both social science and of law. In social science, the case against such a procedure has been articulated most clearly by Popper $^{3}$ but puzzled already Hume. ${ }^{4}$ This realisation motivated Hume already at the early stage to suggest that what he called 'moral explanations', used in practical matters are probably a better template for letting us know what is going on than efficient causal inferences. ${ }^{5}$ In law, the objection to confirmatory strategies is evidenced by the fact that prosecutors are held to follow up on exculpatory evidence and to present it to the court instead of just 'nailing' the accused by telling one causal story.

This leads me to the second point. Given the standing of this epistemological principle of caution in regard to confirming evidence, it seems indeed strange why the above arguments concerning the emergence

${ }^{3}$ K Popper, The Logic of Scientific Discovery (Routledge, London, 1992).

${ }^{4}$ Hume pondered the issue of how much evidence is enough to justify an inference as to the 'cause' of a phenomenon, particularly since causality is not in the 'things out there' but supplied by the mind. Usually Kant is credited with this argument but - contrary to the common misreading of Hume - a careful reading of the Treatise shows that it was not only the problem of induction that troubled Hume but the deeper issue of causality, i.e. the 'constant conjunction' which the mind supplies; see D Hume, A Treatise of Human Nature (LA Selby-Bigge (ed), Clarendon Press, Oxford, 1896).

5 See D Livingston, Hume's Philosophy of Common Life (University of Chicago Press, Chicago, IL, 1984). 
of a global dialogical sphere and the role of courts in shaping this discourse have got that much attention. Obviously, this 'pull' has something to do with our wishes and the political projects we pursue, so that people who are convinced of the 'cosmopolitanism in the making-argument' are more likely to discount discordant facts. Among the disconfirmations would be the obvious realisation that the mutual 'learning', e.g. among the judiciary, is likely to remain quite uneven since, at best, it is rather restricted to the courts of a few liberal states. Drawing on the decisions of courts of Iran, China, Peru or Egypt or Bangladesh is not likely to be considered, despite the fact that doing so could enhance the cosmopolitan scope of the alleged 'learning' exercise.

This realisation has some further corollaries. Formerly, a kind of Calhounian compromise was quite common among legal scholars stipulating that, for example, a UN General Assembly resolution which attempted to articulate the opinio juris of an emerging custom should at least have also some form of a qualitative majority of the most representative states of the First, Second and Third World. Now, however, there is a clear preference for a type of liberalism defined by free markets, secure property rights and the rule of law (giving various human rights the priorities that 'we' prefer). Quite obviously there is a didactic and a mainstreaming (if not to say paternalistic) tinge to all the talk about learning and dialogue since the direction of the information flow is quite clear, not only to post-colonialist; needless to say, the same pattern prevails within Europe as it shines through also in the contributions about a 'constitutionalisation' of the Strasbourg court. ${ }^{6}$

True, such a didactic urge need not necessarily lead to further and further conceptual stretching of the notion of 'public'. ${ }^{7}$ We all know that not everything that is widely talked about is already a public issue as gossip demonstrates. Neither does this didactic have to engender some form of judicial activism, as is evidenced by some commonly used conceptual escapes such as the 'margin of appreciation' or the subsidiarity principle. ${ }^{8}$

6 See in this issue G Ulfstein, 'Transnational Constitutional Aspects of the European Court of Human Rights' (2021) 10 Global Constitutionalism 151-174; and W Sadurski, 'QuasiConstitutional Court of Human Rights for Europe? Comments on Geir Ulfstein' (2021) 10 Global Constitutionalism 175-185.

7 Here the contorted use of 'custom' for political projects de lege ferenda comes to mind but - strangely enough - also the 'narrowing' of concepts, such as that of humanity to 'liberal' people (à la Rawls), thereby taking them as partes pro toto for 'humanity' in general.

8 See in this issue A Follesdal, 'International Human Rights Courts and the (International) Rule of Law: Part of the Solution, Part of the Problem, or Both?' (2021) 10 Global Constitutionalism 118-138; and G Palombella, 'Non Arbitrariness, Rule of Law and the "Margin of Appreciation": Comments on Andreas Follesdal' (2021) 10 Global Constitutionalism 139-150. 
But historical experience tends to confirm the drift to activism or - what the military would call - to 'mission creep'. If there is no direct jurisdictional empowerment, judges can always construe a functional necessity, attach the legislative innovation to something already in use (such as a question of social policy to labour law) or invoke - as in the case of competition policy - the need of uniformity to secure the functioning of markets, silencing thereby nicely 'subsidiarity' and other cautionary principles.

Whether one sees such expansive measures as an issue of 'education' or of forcing people to do what is best for them, depends, of course, upon one's 'theory' and political projects. The latter invites flights from reality into 'ideal theorising', well familiar since Platonic times. But it also engenders a certain impatience with deliberation and criticism, directing activity towards a type of knowledge that takes production (techne) as its paradigm. Alas, Bentham's legislator utilising his felicific calculus is now dispensing justice in robes by swinging a gavel! ${ }^{9}$ Nevertheless, one thing seems to be impossible in this context: to sell this form of paternalism (at best) or of 'coercive felicification' (Zwangsbeglueckung) as an instantiation of emancipation, or to celebrate this as a victory for law which has finally opened the gates to the kingdom of ends by dispensing with politics. It is just a politics by other means, as often suggested, but could it not also be that it is also a politics in which some traditional remedies for insuring the accountability of the 'rulers' (or rule-handlers) have been weakened?

Traisbach is therefore right in pointing to some obvious dissimilarities between the debates prevailing in a well-established public sphere, deliberating about policies, and the idealised 'transnational judicial public sphere' where courts compete and struggle for influence over the authoritative interpretation. His remarks, however, also raise the further question of whether the notion of a 'domination-free discourse' has any practical meaning at all. It is, after all, one thing to build ideal types in order to analyse different forms of communication; in that context the arriving at a common understanding can be analysed in terms of (idealised) preconditions. It is, however, quite another thing to take these ideal types as occurring in actual practice in different 'spheres'. This move mistakes an ideal type, which is a conceptual construct created for heuristic purposes, for an actual process characterising social interactions, allegedly constituted by distinct 'interests', as Habermas once argued.

In short, in the public debates of real life, strategic interests always interact with 'technical' issues of viability and with the waxing and waning

9 See, e.g., R Dworkin, Justice in Robes (Belknap Press, Cambridge, MA, 2008). 
of the need to compromise in order to come to a joint decision that is binding on all. Actually, it is hardly imaginable how any decision could ever be made, if anyone in public debates could always raise any issue at any time, as the 'ideal speech' situation à la Habermas required. Here rules of order are necessary - even for 'ideal participants' which these ideal speech situations require - as otherwise no persuasion and convergence on a definite outcome is likely to emerge.

II.

When compared to public debates, Traisbach is also right in pointing out that the judicial discourse is much more constrained. However, he is perhaps also too optimistic about the deliberative potential of contemporary political debates, considering what we observe at present in the media circuses, be they election campaigns, talk shows or personal interest stories which are brought to our parlours or bedrooms by media celebrities masquerading as 'experts' or reporting from the 'very spot'. Thus despite the liveliness or acrimony of the discussions, the adequate phrasing of a problem or the discovery of a common ground becomes a fortuitous rather than intentional outcome. Instead, 'showing flag', communicating one's feelings and professing that one is on the right side have increasingly become the necessary cues for reaching a public, which has become one of spectators not of agents.

While of course some of these pathologies can also be discovered among legal professionals, it is nevertheless true that the legal discourse is considerably more structured than the political one, since only certain reasons are allowed, i.e. those which have legal standing, thereby ruling out those which could provide good reasons (functional ones, moral ones, etc.) but lack the legitimacy of coming from a court which can draw on the 'credit' given to the law.

The upshot of this argument suggests that it seems useless to conceive of 'the better argument' in abstracto, as has been common during the last two or three decades since different discourses have different criteria for admitting or attributing weight to arguments. No judge could, for example, 'accept' without further ado Peter Singer's position for poverty reduction or animal rights even if, given certain philosophical premises, these arguments could be shown to be 'better' than the strange set of customs and convictions that undergird our 'normal' social existence and which are reflected in our laws. Nevertheless, while abstract philosophical arguments are not totally excluded, they can usually be raised, if at all, only as obiter dicta. The exception is when they have standing within the law such as representing an established precedent which, of course, also raises the question whether 
with the increasing de-formalisation of law and its sources new rhetorical topoi emerge. ${ }^{10}$

Here Jan Klabber's searching examination of 'functionalism' in both international law and the emergence of international organisation in international relations is illuminating, as it also throws much light on the recent discussion of global governance. ${ }^{11}$ Thus while the notion of 'function' seems to provide a clear bridge between the disciplines, a closer investigation of the use of the term shows that neither within the legal nor the political discourse it means the same thing since its emplacement in different sematic fields produces its meanings.

As we can gather also from the present discussion in economics, what is functional for the financial sector might be dysfunctional for the economy as a whole (due to the creation of bubbles). Similarly, in law what might be 'functional' from an administrative perspective might be dysfunctional from a constitutional one, as the search for a lack of 'friction' - dominating technocratic thinking - might be undermining the 'check and balances' which are - in a way - disabling for a certain set of activities, but might be functional for a political and legal system from a constitutional point of view. Similar restrictions apply in cross-disciplinary discourses: While low transport costs and lack of barriers are functional for trade, the same is not true for the environment, or public health, or security. Important problems are not only made invisible by this use of the term, but also certain levers for taking care of the negative externalities are thereby mystified and/or de-legitimised.

Some further corollaries follow from this. Given the inevitable indeterminacy of many public debates, law has - different from potentially interminable philosophical debates - to arrive at a decision, and thus the reasonableness of law cannot mean that 'law' can resolve all disputes by resorting to purely procedural norms or ideal principles in order to decide substantive issues. Some principles are of course 'procedural' and intrinsic to the legal enterprise. Thus, audiatur et altera pars (the other party has to be also heard - and given a chance to rebut arguments) is certainly such a purely formal principle (as is: treating alike cases alike). But it is also clear that such abstract principles cannot decide controversies without recourse

10 Here the 'obiter dictum' in the Barcelona Traction case of obligations erga omnes shows the problematique. It has given rise to speculations about a jus cogens that raises interesting philosophical issues but offers surprising little guidance - in the absence of a clearly institutionalised judicial process. As to the proper scope and limitations of these concepts, see Case Concerning Barcelona Traction, Light, and Power Co., Ltd (Belgium v Spain), Judgment 5 February 1970, [1970] ICJ Rep 3.

$11 \mathrm{~J}$ Klabbers, 'The Emergence of Functionalism in International Institutional Law: Colonial Inspirations' (2014) 25 European Journal of International Law 645. 
to more substantive understandings and supporting reasons for the analogies we use. This is the case when we use, for example, the term 'weapon' analogously for an otherwise innocent pencil, when a person attempts to ram it into the body of an opponent, or why 'passive smoking' (exposing me to cigarette smoke) is considered a tort.

A second corollary is that, since law cannot 'will' its own implementation simply into existence, it has to rely on the 'executive' arm. Here Traisbach correctly points to the importance of another constraint: the embeddedness of the judicial process within the larger political processes, for which the discourse of checks and balances is paradigmatic. This aspect is often left unattended when focusing on law and politics only through language, but forgetting that full-fledged discourses involve not only talking and acting, but also disciplinary measures and routines, as Foucault was never tired of pointing out. That such a full-fledged discourse, which effectively and reliably links law and politics in the international realm, is largely lacking in discussion about the future global order - aside from some discussion about enforcement measures by the Security Council and its questionable practices - is hardly news. And it is neither news that that due to the problem of decay of the political processes - not only in 'failed states' but also in formerly well-constituted societies - one can observe a tendency to usurp the now empty spaces by verbal expressions and their fetishisation. Here the claims emerge largely from doctrinal speculation or from a legal theory that has become little more than an ideal 'theory of adjudication' while camouflaging the problem of power (Weber's Herrschaft through law). Thus given the lack of a well-institutionalised mode of making out of the 'will of all' an obligatory volonté générale, the call for a Platonic 'nocturnal council'12 ('speaking' the law) becomes the dernier cri for disguising power. After all, someone has to decide; and if it is not politics and the 'fictitious' people serving as the legislator, then it has to be the law itself. And justice will have to come in robes.

As the Schmittian executive was above 'the people', so now a 'court' is above the 'global civil society'13 - even if it is not quite clear which of the existing courts could shoulder this task, as the tribunals do not stand in a clear order vis-à-vis each other. Furthermore, if this aporia is taken as an argument for a 'World Court of Human Rights', then the question still remains in what order of super- and sub-ordination this court should stand to other existing courts and how its decisions can be legitimised given the

12 Plato, The Laws, Book X, 961B 6-8.

${ }^{13}$ It is also strange that such a court, if it came into existence, would have to rely on a political decision mechanism, i.e. the counting of votes - a rather strange fallback on the 'politics' one wanted to escape. 
different conceptions of constitutional order and of the rule of law in its different historical manifestations. ${ }^{14}$

\section{III.}

There are two further interrelated problems with this narrowing of focus from the interaction of the political and legal discourse and their respective 'publics' (or lack thereof) to one of law, and with the prevalent tendency of reducing the legal problematique to adjudication, even though - quite paradoxically - the claims made in this context are frequently rather imperial. One is the issue of 'discourse' which in this case is still beholden to some 'ideal theory' - in our particular case to what Judith Shklar ${ }^{15}$ once so aptly portrayed as 'legalism'. The animus to develop (without much further ado) 'the law' in the name of a teleological reading of 'humanity' - as one reading of Kant suggests - remains in tension with the notion that the legal process has to be embedded in actual practices and that to found law on doctrine only - even if it is for noble purposes - is to court disaster. After all, even highest court decisions can be ignored as, for example, the US Supreme Court's Dred Scott decision ${ }^{16}$ and the referendum in BosniaHerzegovina ${ }^{17}$ show.

This raises the second problem. If discourses are restricted to doctrinal pronouncement and legitimise themselves solely or largely through their own 'logic' à la Luhmann, ${ }^{18}$ then problems of 'structural coupling', i.e. of forging the links to the logic and practices of other systems, arise. Legitimisation can then no longer be simply deduced from the logic of one system, as resistance will sooner or later arise through the responses of other systems. To insist then on the primacy of law and endowing it with legitimacy by stressing its formal criteria such as non-retroactivity,

14 On the different conceptions of the rule of law, see in this issue J Waldron, 'The Rule of Law and the Role of Courts' (2021) 10 Global Constitutionalism 91-105; and BZ Tamanaha, 'Always Imperfectly Achieved Rule of Law: Comments on Jeremy Waldron' (2021) 10 Global Constitutionalism 106-117.

15 J Shklar, Legalism: Law, Morals and Political Trials (Harvard University Press, Cambridge, MA, 1986).

16 Dred Scott v Sandford, Decision, U.S. Supreme Court 60 U.S. (19 How.) 393 (1856).

17 See BBC, 'Bosnian Serb Referendum Backs Disputed 9 January Holiday' 25 September 2016) <https://www.bbc.com/news/world-europe-37465653>. The issue was the declaration of a national holiday for the Republica Srpska, which had been struck down in November 2015 by the Constitutional Courts of Bosnia-Herzegovina because of the potential discrimination of the non-Serb parts of the state.

18 See, e.g., G Teubner, 'The Two Faces of Janus: Rethinking Legal Pluralism’ (1991) 13 Cardozo Law Review 1443; A Fischer-Lescano and G Teubner, Regimekollisionen (Suhrkamp, Frankfurt am Main, 2006). 
publicity and equal treatment is problematic since the real question is not the problem of the autopoietic justification of law by itself, but the clash among different forms of 'functional' legitimisation through different systems. In this case 'structural coupling' can provide a solution only if $e x$ ante it is clear that 'law' will prevail and which court will have to take the case and authoritatively decide it. Could law then strengthen its grip by utilising some other decision criteria, perhaps forego some of its own by looking to other disciplines, as proposed by the law and economics school? This last proposal raises a whole host of questions that would need serious research. But it might also be that law undermines thereby its own legitimacy by being just an adjunct to 'market forces' and their unfettered dynamics.

Such calls for caution are, however, frequently met by charging their proponents with 'atavism' opposing 'progress' and being beholden to a past that never was. But I think both political scientists and legal theorists have often taken the easy way out when confronted with such dilemmas. Whatever the merits of such an interpretation may be, we should realise that the standard tropes in the 'progressive narratives' equally also have some 'darker' sides to them, as Foucault ${ }^{19}$ and also some critical legal scholars have pointed out. Appeals to a 'future' that we cannot know as the latter is not an open book for us, are as phantasmagoric as a pristine past that never was. As historical experience suggests, they harbour the same totalitarian dangers.

Similarly, trying to resolve these legitimacy issues through a resort to 'formal' criteria such as the 'publicity' of law, which allegedly thereby provides the 'neutral meeting ground', seems to me far too narrow. Particularly, in our times when 'central' institutions are being dissolved by increasing interdependencies, accountability either evaporates entirely or is available only to those who have privileged access to 'private means' of conflict resolution. Claims to neutrality then sound hollow not only because they camouflage the not at all 'neutral' political victories of former times which have been transformed through law into the way of 'how things are', but also because legitimacy is not of one cloth and there remain different sources of legitimacy which stand in tension with each other. At least that much we can gather from the discussions of input and output legitimacy, or the debates about 'consent' and 'rights as trumps'.

Thus, the rule by law - even a law vetted by publicity principles - does little for the notion of human autonomy, which we consider today (as did the Kant of 'yesteryear') an important aspect of the rule of law both 
domestically and internationally. ${ }^{20}$ This is why Kant, for example, was quite careful in limiting the cosmopolitan law to a right of visit only and in ruling out a right of intervention on the basis of moral principle. ${ }^{21}$ Of course, that leaves us with the quandary what to do when sweet reason fails to convince dedicated perpetrators of atrocities. Then we seem to be in the same position as the Romans when emperor Nero is said to have proposed to the Senate - when queried about his responses to several hostile legions moving in on Rome - that he was going to 'sing to them' in the expectation that they will be moved.

True, in Kant's writings we also can find the passage that grave breaches of the rule of law are a matter of everybody's concern ${ }^{22}$ exposing a potentially 'tougher' side of the 'liberal peace'. This interpretation then gave rise to a 'Wilsonianism in boots' and provided the justification for a world war intended to end all wars. It also offered, more recently, the justification for coalitions of the willing to carry the burden of regime change. Of course, the easy answer for lawyers is that these aberrations have to be squarely laid on the doorsteps of the political system and its leaders since these regressions into imperialism have nothing to do with 'the law', which provides instead an alternative to those failures by advocating a humane 'governance'. It is through governance that power can be transformed into rule, caprice into principled choices and violence into reason so that no actual incorporation into a new 'whole', which Kant so feared, was necessary.

As in the case of the Kantian 'universal concern', the first point can be valid, but the conclusions drawn from it need not be. First, if in a world of (judicial) governance power becomes so diffuse, whom can I hold accountable? This is not only the problem of the 'many hands', it also means that the very purpose of technocratic rule by experts gets mixed up with the issue of judicial independence. Thus international juristocrats ${ }^{23}$ have to be both technocratic experts and independent umpires and can use competing legitimisations. Whether this strengthens or weakens accountability is, at best, an open question.

Second, even if it is true that governance - different from 'governments' need not rely on territorial control, the conclusion that this observation proves the benign nature of the regime does not follow. Domination can be achieved - even more easily so - by exclusions rather than by direct

20 I Kant, 'The Metaphysics of Morals: Introduction to the Theory of Rights and The Theory of Right, Part II: Public Right' in HS Reiss (ed), Kant's Political Writings (2nd edn, Cambridge University Press, Cambridge, 1991) 131.

21 I Kant, 'Perpetual Peace' in Reis (n 20) 116-30.

22 Ibid.

$23 \mathrm{R}$ Hirschl, Towards Juristocracy: The Origins and Consequences of the New Constitutionalism (Cambridge University Press, Cambridge, MA, 2007). 
coercion. And here the panoply of the 'entitlements', which law bestows on - or withholds from - certain actors, is in most cases sufficient to do the trick. ${ }^{24}$ Curtailing access to markets might have crippling implications for those not complying 'with the rules', and even benign neglect might have quite similar results as direct extortion. In short, as the discussion of structural and productive power has shown, ${ }^{25}$ the old Weberian notion of power tied directly to the actions of interacting agents is woefully inadequate for understanding social reality.

IV.

Thus, before we get on with 'finishing' the Kantian project of universal concern - despite the caution of its original author - and jump the gun by thinking that this universal human autonomy can only be guaranteed by an extensive catalogue of natural or human rights administered by judges, we better consider also a political alternative that Hume proposed. It has to do with both the development of conventions and habits that stabilise interactions, endowing certain solutions (paradigmatic cases) with saliency and with developing a certain competence in using them - not only among the members of the bench - but by all who participate in civil life 'through commerce and conversation'. ${ }^{26}$

This alternative relies on a variety of different institutional solutions: the development of sentiments (solidarity) that creates some generalised goodwill among a public and provides the credit for securing expectations which let us go on despite inevitable disappointment; the work of magistrates who make it their interest to safeguard the public interest in return of salaries (rather than grants of benevolence from the 'sovereign') and who are appointed through competition to counteract venality (here the check and balance argument of republican thought does its work); entrusting representative institutions with the legitimisation of legislative or executive acts; and finally wielding the power of the purse if policies turn out badly despite their original approval. ${ }^{27}$ In such a set-up and the

${ }^{24}$ D Kennedy, A World of Struggle: How Power, Law and Expertise Shape the Global Political Economy (Princeton University Press, Princeton, NJ, 2016).

25 M Barnett and R Duvall, 'Power and International Politics' (2005) 59 International Organization 39.

${ }^{26}$ D Hume, 'On Essay Writing' in D Hume, Essays, Moral, Political and Literary (EF Miller (ed), Liberty Fund, Indianapolis, IN, 1987) 47-58.

27 For a fuller discussion see F Kratochwil, 'Re-thinking Interdisciplinarity by Re-reading Hume' in N Rajkovic, T Aalberts and T Gammeltoft-Hansen (eds), The Power of Legality: Practices of International Law and Their Politics (Cambridge University Press, Cambridge, 2016) 29. 
processes it engenders courts have to compete with other institutions (legislatures) and with shifts in public opinions as well as with the changing coalitions in parliaments that fund the policies. Thus there is not one and only one supreme authority but a process among different parts of the system competing for the 'solution' that sticks and becomes thereby 'settled'.

V.

This leads me to the third and last point which Hume so artfully articulated and Traisbach hints at but which we all will have to ponder much more seriously in the future: it is the problem of judgment. No set of rules in the world and no courts to boot will be able to 'speak' what the law is if their members lack the power of judgment. Judgment, as Kant makes us aware, is not the same as the capacity to reason either through inductive generalisation or deductive entailments. It rather requires the ability to see the similarities and differences among situations and cases and to provide acceptable justifications for why one similarity should count and not be rebutted by another dissimilarity when we fit the facts to the norms and principles and/or pick among the principles which seem to be 'fitting' best the facts.

Such a capacity Kant likens to commonsense (Mutterwitz) ${ }^{28}$ and opposes it directly to stupidity (Dummbeit), i.e. proceeding with the ingrained routines without circumspection and attention to the particularities of a case. Kant observes that this flaw (Gebrechen) is rather common among professionals, even university teachers. In the case of reasoning with rules or principles it is the incapacity to 'get the point', i.e. to see what rules are for, and to make in this light the necessary adjustments (exceptions, exemptions) to the applicable rule, justify the choice among competing rules or conflicting principles. Such a capacity requires both imagination and experience that is acquired by being part of ongoing interactions and living the 'civil life'. But it also needs as a background the thick sedimentation provided by the spoken and unspoken traditions of an identifiable group - not a largely imaginary world community - that has to include both the directly affected and the more peripheral bystanders without making the law subservient to prophetic visions of a future we cannot fathom.

28 See I Kant, Kritik der Reinen Vernunft (W Weischedel (ed), Suhrkamp, Frankfurt am Main, 1974) vol III.1, Vorrede A 174 and B 135, the gloss that stupidity is a 'flaw that cannot be cured'. 